UDC 35.071

JEL Classification: D71, D73

DOI: 10.15587/2312-8372.2018.153343

\section{Shatokhina Yu., Khovaylo I.}

\title{
DETERMINATION OF THE DIRECTIONS OF IMPROVING THE ORGANIZATIONAL STRUCTURE ON THE EXAMPLE OF THE ACTING VILLAGE COUNCIL
}

Об’єктом дослідження є процес формування ефективної організаційної структури селищної ради для забезпечення виконання ї численних завдань, обумовлених необхідністю вирішення складних соціальних та економічних проблем, типових для даного регіону. Одним з найбільш проблемних місць є об'єктивне визначення напрямів вдосконалення організачійної структури діючої сільської ради з урахуванням результатів ї діяльності.

Для усунення суб'єктивного підходу використовувалась розроблена методика оцінювання діючої організаційної структури селищної ради, яка передбачає наступний алгоритм дій:

- розробку номенклатури показників ефективності роботи та їх чисельних значень;

- розробку анкети з обраними показниками;

- проведення анкетування;

- математичну обробку результатів дослідження;

- детермінацію з урахуванням отриманих результатів напрямів вдосконалення діючої організаційної структури.

В роботі використано статистичні методи - розрахунок відсотку задоволених від загальної кількості опитаних, а також визначення середнього значення задоволеності у балах при п'ятибальному оцінюванні.

Отримано в кількісному вираженні дані про задоволеність респондентів роботою Любецької селищної ради (Україна), яка є типовим представником створених нещодавно місцевих рад. Так, з усіх 10 питань

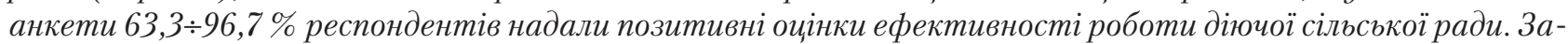

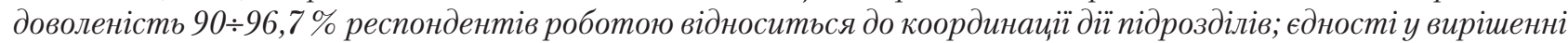
складних питань; залагодженні конфліктів керівниками структурних підрозділів; швидкості реагування співробітників на складні питання; узгодженості цілей підрозділів селищної ради. До 73,3 \% респондентів з розумінням відносяться до стилю управління голови селищної ради; послідовності у діях керівнищтва.

Завдяки анкетуванню отримано можливість чисельного визначення (у відсотках) задоволених роботою діючої організаційної структури, а також очінити за п'ятибальною шкалою середній бал задоволеності. Зокрема, середній бал (серед респондентів, які задоволені роботою Любецької селищної ради) дорівнює

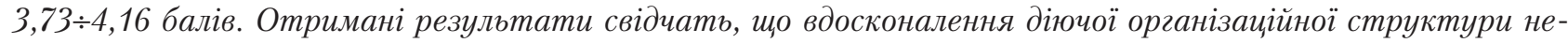
обхідно здійснювати таким чином, щоб з усіх десяти розглянутих напрямів забезпечити максимальну ефективність та розуміння, а також підтримку з боку громади. У порівнянні з існуючими підходами запропоноване чисельне оцінювання задоволеності за локальними встановленими критеріями забезпечує зростання інформативності та об’єктивне визначення напрямів вдосконалення організаційної структури діючої сільської ради з урахуванням результатів ї̈ діяльності.

ключові слова: територіальна громада, організачійна структура, напрями вдосконалення, методика оцінювання.

\section{Introduction}

The difficult social, economic and environmental situation in Ukraine has led to significant transformational processes related to the revision of social relations. Significant changes are required by the general system of organization of public authority in Ukraine, as required by the democratization of social relations and the decentralization processes associated with it [1-3].

The issues related to the implementation of local selfgovernment as the primary link in the organizational structure of government bodies have a particular relevance. Continuing attention requires the functioning of both each individual subsystem, and their relationship to ensure the ability to effectively solve issues of local importance in accordance with the Constitution and laws of Ukraine and contribute to the socio-economic development of the country.

\section{The object of research and its technological audit}

The object of research is the process of formation of an effective organizational structure of the village council to ensure the fulfillment of its numerous tasks, which are caused by the need to solve complex social and economic 
problems typical of this region. One of the most problematic places is the objective determination of directions for improving the organizational structure of the existing village council, taking into account the results of its activities.

The subject of research is the organizational structure of the Liubech village council (Ukraine).

For those territorial communities that within $2 \div 5$ years have already passed the first steps on the difficult path to local self-government at the village or village level and have a certain operating organizational structure, the question arises how to increase its efficiency and improve. For example, in Chernihiv, the Liubech village council [4] is trying to cover the many functions of the development of the territorial community. These functions include the preservation of the environment, educational, recreational, social functions, protection, management of communal services, organization of sports and leisure. The Liubech village council cooperates on these issues with the Chernihiv Center for Local Government Development, established with the support of the U-LEAD Program with Europe. Also village council is supported by the Ministry of Regional Development, Construction and Housing and Communal Services of Ukraine.

For this organization, the question of how to improve the existing organizational structure to ensure the fulfillment of its many tasks is also important.

A significant number of problems that arise in territorial communities when they are created and the implementation of powers, reveals an analysis of literary sources. Thus, the territorial communities of Chernihiv region, one of the largest in the region's territory in Ukraine, receive the need to solve social and economic problems [4] in the face of a complex environmental situation caused by the consequences of the Chernobyl accident. This study will be conducted on the example of the Liubech village council, the problems of which are typical for many communities.

\section{The aim and objectives of research}

The aim of research is improvement of the organizational structure on the example of the Liubech village council as the primary link of local governments. Compliance with the aim the following tasks are determined:

1. To develop an assessment methodology for analyzing the effectiveness of the activities of the existing village council (using the example of the Liubech village council).

2. On the basis of the results of experimental and analytical research, to carry out the determination of the directions of improving the organizational structure of the studied village council.

\section{Research of existing solutions of the problem}

Providing the population of the villages of Ukraine with work, creating the conditions necessary for living is considered a priority task [5]. In [6], the unsatisfactory situation in the Chernihiv region in the labor market is shown. It is emphasized that the labor market affects the volume of social production, the level and quality of life of the population, the socio-economic development of the country. As of 01.01 .2017 , there were 17 people for each vacancy in the Chernihiv region. Promising tasks are the creation of new jobs by small businesses.
When creating new jobs, as revealed in [7], special attention is required for special training of business entities, their introduction of quality management systems, determining the ability to enter the global market for products and services.

The problem of improving the organizational structure of various organizations is covered in many publications. Thus, in [8] considerable attention is paid to the analysis of the influence of organizational structure on organizational creativity and the commitment of employees. According to the results of a study [8] in Iranian municipalities, it is revealed that there are positive, significant connections between the elements of the organizational structure and organizational creativity, which must be taken into account in similar cases.

From the review of the literature it is clear that the value of the organizational structure is being studied in various fields. Thus, in [9], when studying the influence of organizational structures on the organization of training and individual adaptive work, 216 employees of hotel establishments did not reveal a specific dependence by a survey method.

Modern requirements for human resource management are of particular interest to researchers in organizational structures in Czech and Slovak organizations [10]. Let's consider the organizational structure of personnel, as a structure in the department of human resources, which distributes functions. New roles of HR managers in organizations, including an understanding of strategic goals, support for change, are being identified. Conclusions on the improvement of the organizational structure are made on the basis of the analysis of data obtained from a qualitative and quantitative survey.

In [11], satisfaction with the organizational structure is analyzed by interviewing members of the Association of Nurse Practitioners of the State of New York in connection with the projected increase in the number of medical staff in medical institutions. The research results are used to improve organizations to create an enabling environment for the work of medical personnel.

In [12], the problem of improving existing organizational structures or creating new ones that have arisen in Italian universities during the implementation of a specific technology transfer policy is considered. It has been established that University technology transfer services can be grown internally, for example, expanding their staff, or externally, for example, pooling resources, creating new organizational structures.

Using the example of the development of petrochemical enterprises, the authors of [13] find that the development of an organizational management structure should begin with the formulation of an organization's strategy.

The use of quantitative methods is used to implement organizational changes in the Dutch public organization in [14]. The results obtained in this paper show that bureaucratic organizations can effectively implement organizational changes. It emphasizes the need for attention to the functions of supervisors during organizational changes in public organizations.

Thus, given the literary sources, it is clear that there are no uniform recommendations for improving the organizational structure. When looking for directions to improve the organizational structure, it is necessary to take into account the specifics of this organization and use quantitative methods. 


\section{Methods of research}

Elementary-theoretical analysis of the effectiveness of the current organizational structure is used, which allows to identify the nomenclature of important indicators, as well as the measurement of these indicators.

To evaluate the effectiveness of the existing village council in order to improve its organizational structure, the following procedure has been developed:

a) analysis and development of the nomenclature of the organizational structure performance indicators and their numerical values that are important for a given object;

b) development of a questionnaire with selected indicators;

c) conducting a survey;

d) mathematical processing of research results and determination of directions for improving the current organizational structure.

Based on the analysis of the Charter, information on the work of the existing village council [4], the following indicators are recognized as important for a given object by the performance indicators of the organizational structure:

- How do you assess the style and standards of management of the chairman of the village council?

- Do you consider the leadership of the village council consistent in their actions?

- Do you agree with the approaches of the management to work?

- Do you think that all employees of various departments of the village council equally represent the future of society?

- How effective is the interaction of different departments?

- Is it possible to consider the actions of various units coordinated?

- Do the employees of the organization show unity in solving complex issues?

- Are the heads of structural units able to handle conflict situations in the management process?

- Do you consider the agreed goals of the various divisions of the village council?

- Do the village council employees quickly respond

to issues that require urgent solutions?

The answer to each question provided for the number of points from 1 to 5 . Moreover, the number of points from 1 to 2 is the rating indicator «unsatisfactory», the number of points from 3 to 5 is the rating indicator «good».

After the questionnaires were made, an anonymous survey was conducted, the target group of the study was the staff of the Liubech village council in the amount of 30 people. The experimental results of the questionnaire process were then used to calculate the selected satisfaction indicator $\left(P_{i}\right)$ of respondents with the work of the current organizational structure. The calculation of the indicator $P_{i}$ is carried out according to the formula:

$$
P_{i}=\frac{n_{i}}{n} \cdot 100 \%,
$$

where $P$ - the corresponding value of the analyzed index, \%; $n_{i}$ - the number of specific answers; $n$ - the sample size (number of respondents).
In order to be sure that this sample reliably and accurately corresponds to the general population [15] of the entire organization, not only the satisfaction index $\left(P_{i}\right)$ in percent is calculated, but also the representativeness error $\left(m_{i}\right)$. To calculate the error of representativeness $m_{i}$, the formula is used:

$$
m_{i}= \pm \sqrt{\frac{P \cdot q}{n-1}}
$$

where $P$ - the corresponding value of the analyzed indicator, $\%$, and the indicator $q$ is calculated by the following formula:

$$
q=(100 \%-P \%) \text {. }
$$

To visualize the obtained data, the «Petal diagram» is used, which is built using Microsoft Excel.

\section{Research results}

According to a certain algorithm of actions, after conducting a survey, a mathematical processing of the survey results is carried out for the subsequent determination of the directions for improving the current organizational structure.

The results of mathematical processing of experimental data are presented in Table 1. It is revealed that the overwhelming majority of respondents provide positive ratings.

As can be seen from the Table 1 data, the calculated satisfaction rate $P_{i}>3 m_{i}$, that is, all the results are representative, reliable, they can be taken into account to improve the structure of the Liubech village council.

The survey results show that not all areas of work are implemented as successfully as possible. It is noteworthy that more than $93 \%$ of respondents are satisfied with the speed of response, that is, the conscientious work of the team on solving important issues is obvious. As can be seen from the results of the survey, satisfaction with $90 \div 96.7 \%$ of respondents with the work of the Liubech village council relates to the following areas of work:

- coordination of actions of the village council units;

- unity in solving complex issues;

- conflict resolution by heads of departments;

- speed of employee response to complex issues;

- consistency of the objectives of the village council units.

Table 1

The results of the survey on employee satisfaction with the work of the Liubech village council

\begin{tabular}{|c|l|c|c|c|c|}
\hline No. & $\begin{array}{c}\text { Abbreviated wording of the } \\
\text { questionnaire }\end{array}$ & $\begin{array}{c}\text { Tatal number of } \\
\text { respondents, } n_{\boldsymbol{r}} \\
\text { people }\end{array}$ & $\begin{array}{c}\text { Number of } \\
\text { satisfied, } n_{i r} \\
\text { person }\end{array}$ & $\begin{array}{c}\text { Satisfac- } \\
\text { tion rate, } \\
P_{i,} \%\end{array}$ & $\begin{array}{c}\text { Represen- } \\
\text { tativeness } \\
\text { error, } m, \%\end{array}$ \\
\hline 1 & Management style & 30 & 19 & 63.3 & 8.95 \\
\hline 2 & Sequence & 30 & 22 & 73.3 & 8.2 \\
\hline 3 & Work approaches & 30 & 19 & 63.3 & 8.95 \\
\hline 4 & Understanding of the future & 30 & 25 & 83.3 & 6.92 \\
\hline 5 & Interaction efficiency & 30 & 25 & 83.3 & 6.92 \\
\hline 6 & Coordination & 30 & 27 & 90.0 & 5.57 \\
\hline 7 & Unity & 30 & 29 & 96.6 & 3.36 \\
\hline 8 & Conflict resolution & 30 & 27 & 90.0 & 5.57 \\
\hline 9 & Response speed & 30 & 28 & 93.3 & 7.33 \\
\hline 10 & Consistency of goals & 30 & 29 & 96.7 & 3.32 \\
\hline
\end{tabular}


Satisfaction with $83.3 \%$ of respondents refers to the following areas:

- understanding by the staff of the village council of the future society;

- effectiveness of the interaction of structural units.

Only $63.3 \div 73.3 \%$ of respondents are satisfied with such components of the work of the Liubech village council as:

- management style chairman of the village council;

- consistency in the actions of management;

- leadership approaches to the conduct of work.

Important information is also carried out to determine the average score of the assessment of the village council among satisfied respondents. It turned out that with the five-point assessment planned in the questionnaires, the average score even in that part of the respondents rated the work positively, does not reach the maximum and is $3.73 \div 4.16$ points. The results presented with the help of the «petal diagram» in Fig. 1, let's see that there is a significant reserve for improving the work of the village council in all the considered areas.

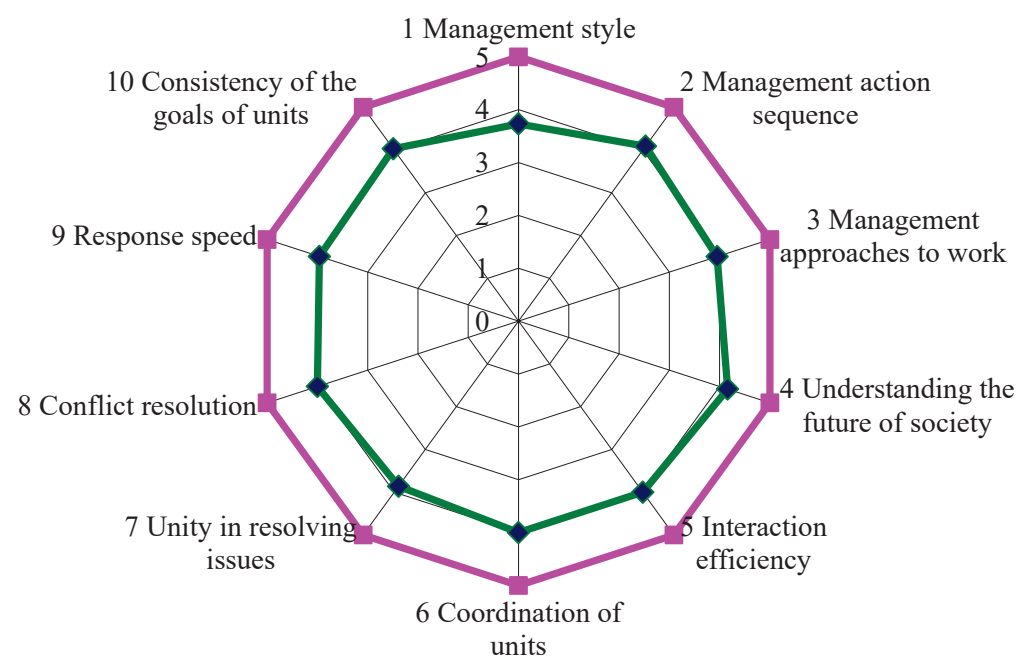

Fig. 1. The average score of satisfaction of Liubech village council

The survey results show that not all areas of work are implemented as successfully as possible. This requires the improvement of the organizational structure with the provision of certain powers to the structural units of the Liubech village council and the chairman of the village council in addressing strategic issues of the development of the territorial community.

\section{SWOT analysis of research results}

Strengths. The results obtained in this paper provide further development of the scientific basis for determining the directions for improving the organizational structure of the territorial community. Experimental verification of the proposed methodology confirmed the possibility of obtaining data necessary for determining the directions of improving the organizational structure of the existing village council.

Weaknesses. An absence in the text of the questionnaire information regarding the age of the respondents is identified as weakness. Because of this, some answers are difficult to explain.

Opportunities. The developed algorithm of actions allows to evaluate the effectiveness of the work of the Liubech village council and the direction of improving its orga- nizational structure and can be used to analyze the work of any village council.

The study can be interesting not only for Ukraine in connection with the developed algorithm of actions when choosing directions to improve the organizational structure, which summarizes the existing trends in taking into account the specifics of the organization and the use of numerical methods in the analysis process.

Threats. The process of improving the organizational structure should be considered as a continuous process, taking into account not only the results of the survey, but also periodic action on the object of study of external factors. For example, changing laws on the economic sphere of domestic production.

Additional costs during the reorganization of the existing organizational structure require a change of powers, possibly due to the creation of new units.

Thus, at this stage, the work of the village council as a primary unit of local governments requires not only constant attention and support, but also further research

\section{Conclusions}

1. A methodology has been developed for evaluating the current organizational structure of a village council (using the example of the Liubech village council), which provides for the following algorithm of actions:

- development of the nomenclature of the organizational structure performance indicators important for a given object and their numerical values;

- development of a questionnaire with selected indicators;

- conducting a survey;

- mathematical processing of research results;

- determination based on the results of improving the current organizational structure.

The obtained results provide further development of the scientific basis for improving the organizational structure of the territorial community.

2. Experimental verification of the proposed methodology in the conditions of the Liubech village council has been confirmed the possibility of obtaining the data necessary for determining the directions of improvement of the organizational structure. Thus, it is revealed that out of all ten questions of the questionnaire, $63.3 \div 96.7 \%$ of respondents gave positive assessments of the effectiveness of the work of the current village council. Satisfaction of $90 \div 96.7 \%$ of respondents with the work of the Liubech village council refers to:

- coordination of units;

- unity in solving complex issues;

- conflict resolution by heads of departments;

- speed of response of employees to complex issues;

- consistency of the objectives of the village council units.

Up to $73.3 \%$ of respondents are sympathetic to the management style of the chairman of the village council; sequence in the actions of leadership. It is also established that the average score (among respondents who are satisfied with the work of the Liubech village council) with a five-point score is $3.73 \div 4.16$ points. 
The results show that the improvement of the existing organizational structure should be carried out in such a way that of all the ten areas considered to ensure maximum efficiency and public understanding and support. In particular, in the identified areas include:

- necessity to improve the organizational structure in ways to improve the consistency in the actions of management;

- interaction and coordination of various departments, the expansion of their powers to address strategic issues of social development.

\section{References}

1. Konstytutsiia Ukrainy: Zakon No. 254k/96-VR 28.06.1996 // Baza danykh «Zakonodavstvo Ukrainy»/VR Ukrainy. St. 98 URL: http://zakon.rada.gov.ua/laws/show/254\%D0\%BA/96$\%$ D0\%B2\%D1\%80

2. Pro mistseve samovriaduvannia: Zakon Ukrainy 21.05.1997. No. 280/97 / Verkhovna Rada Ukrainy. Kyiv: Parlam. vyd-vo, 1997. Issue 24. St. 170. URL: https://pensia.ua/ua/baza-znan/normativno-zakonodavcha-baza/item/692-zakon-ukrainy-280-97-vr-vid21-05-1997-pro-mistseve-samovriaduvannia-v-ukraini?start $=4$

3. Pro dobrovilne obiednannia terytorialnykh hromad: Zakon Ukrainy No. 157-VII 05.05.2015 / Verkhovna Rada Ukrainy. Kyiv: Parlam. vyd-vo, 2015. URL: http://zakon.rada.gov.ua/ laws/show/157-19

4. Liubetska terytorialna hromada. URL: https://liubech-gromada. gov.ua

5. Zbarskyi V. K. Sotsialna infrastruktura sela yak faktor vidtvorennia robochoi syly // Naukovyi visnyk Natsionalnoho universytetu bioresursiv i pryrodokorystuvannia Ukrainy. 2010. Issue 154 (1). P. 152-160.

6. Filipova N. V., Kosach I. A., Khavailo I. P. Rynok pratsi Chernihivskoi oblasti // Skhidna Yevropa: ekonomika, biznes ta upravlinnia. 2018. Issue 13 (14)

7. Shatokhina Yu. V. Intensyfikatsiia vprovadzhennia system upravlinnia yakistiu v Chernihivskomu rehioni // Standartyzatsiia, sertyfikatsiia, yakist. 2015. Issue 4. P. 47-53.

8. Holagh S. R., Noubar H. B. K., Bahador B. V. The Effect of Organizational Structure on Organizational Creativity and
Commitment within the Iranian Municipalities // Procedia Social and Behavioral Sciences. 2014. Vol. 156. P. 213-215. doi: http://doi.org/10.1016/j.sbspro.2014.11.175

9. Kanten P., Kanten S., Gurlek M. The Effects of Organizational Structures and Learning Organization on Job Embeddedness and Individual Adaptive Performance // Procedia Economics and Finance. 2015. Vol. 23. P. 1358-1366. doi: http://doi.org/ 10.1016/s2212-5671(15)00523-7

10. Stritesky M. New HR Organizational Structures in Czech and Slovak Organizations // Procedia - Social and Behavioral Sciences. 2014. Vol. 110. P. 130-139. doi: http://doi.org/10.1016/ j.sbspro.2013.12.855

11. Poghosyan L., Norful A. A., Martsolf G. R. Organizational structures and outcomes of newly hired and experienced nurse practitioners in New York State // Nursing Outlook. 2017. Vol. 65, Issue 5. P. 607-614. doi: http://doi.org/10.1016/ j.outlook.2017.03.001

12. Battaglia D., Landoni P., Rizzitelli F. Organizational structures for external growth of University Technology Transfer Offices: An explorative analysis // Technological Forecasting and Social Change. 2017. Vol. 123. P. 45-56. doi: http://doi.org/ 10.1016/j.techfore.2017.06.017

13. Gurianova E., Mechtcheriakova S. Design of Organizational Structures of Management According to Strategy of Development of the Enterprises // Procedia Economics and Finance. 2015. Vol. 24. P. 395-401. doi: http://doi.org/10.1016/s22125671(15)00695-4

14. Van der Voet J. The effectiveness and specificity of change management in a public organization: Transformational leadership and a bureaucratic organizational structure // European Management Journal. 2014. Vol. 32, Issue 3. P. 373-382. doi: http://doi.org/10.1016/j.emj.2013.10.001

15. Lapach S. N., Chubenko A. V., Babich P. N. Statistika v nauke i biznese. Kyiv: Morion, 2002. 640 p.

Shatokhina Yuliia, PhD, Associate Professor, Department of Public Administration and Organizations' Management, Chernihiv National University of Technology, Ukraine, e-mail: juliaaabest@gmail.com, ORCID: http://orcid.org/0000-0003-3000-1285

Khovaylo Irina, Department of Public Administration and Organizations' Management, Chernihiv National University of Technology, Ukraine, ORCID: http://orcid.org/0000-0001-7923-1896 